\title{
Metabolites from Endophytes of the Medicinal Plant Erythrina crista-galli
}

Daniela Weber ${ }^{\mathrm{a}}$, Susana Gorzalczany ${ }^{\mathrm{b}}$, Virginia Martino ${ }^{\mathrm{c}}$, Cristina Acevedo $^{\mathrm{b}}$, Olov Sterner ${ }^{\mathrm{d}, *}$, and Timm Anke ${ }^{\mathrm{a}, *}$

a Institut für Biotechnologie und Wirkstoff-Forschung IBWF e.V., Erwin-SchrödingerStrasse 56, D-67663 Kaiserslautern, Germany. Fax: +496313167215.

E-mail: timm.anke@ibwf.uni-kl.de

b Cátedra de Farmacologia, Facultad de Farmacia y Bioquímica, Universidad de Buenos Aires, Junín 956, 1113 Buenos Aires, Argentina

c Cátedra de Farmacognosia, Facultad de Farmacia y Bioquímica, Universidad de Buenos Aires, Junín 956, 1113 Buenos Aires, Argentina

d Department of Organic Chemistry, University of Lund, P.O. Box 124, S-22100 Lund, Sweden. Fax: +46462228209. E-mail: Olov.Sterner@bioorganic.lth.se

* Authors for correspondence and reprint requests

Z. Naturforsch. 60c, 467-477 (2005); received February 21/March 11, 2005

Erythrina crista-galli (Fabaceae) is used in Argentinean ethnopharmacology as anti-inflammatory medication, narcotic, desinfectant, and for the treatment of wounds. The common name of the tree is "ceibo" or coral tree. The dominating endophytes in E. crista-galli all belong to the genus Phomopsis as identified by microscopic features and the analysis of their ITS sequences. To investigate a possible contribution of Phomopsis spp. to the metabolites found in the plant, twelve different isolates were cultivated in different media. Besides several new metabolites a number of known compounds were detected: mellein, nectriapyrone, 4-hydroxymellein, scytalone, tyrosol, clavatol, mevinic acid, and mevalonolactone.

Key words: Erythrina crista-galli, Endophytic Phomopsis, Metabolites

\section{Introduction}

Due its North-South extension in the South American continent, the Argentine Republic has a rich biodiversity. There exist ethnopharmacological data on some 1,800 endemic plants, some still being used in folk medicine. However, most of the plants are still unexplored, and there is scarce information about their chemical composition.

It is assumed that all higher plants are associated with endophytic fungi (Hawksworth, 1991; Stone et al., 2000). These fungi form symptomless infections within the plant tissue at some time of their life cycle and can be isolated after surface sterilization (Wilson, 2000). Generally the production of the fruiting bodies starts after the death of the host plant tissue. Some of the endophytes produce bioactive compounds, which provide an advantage for the host. This has been reported for grasses belonging to the Poaceae. Only few endophytes have been extensively studied. However, in same cases unusual and valuable drugs are produced by these endophytic fungi (Strobel, 2002). The important anticancer drug taxol was first isolated from the plant Taxus brevifolia (Wani et al., 1971). Later Stierle et al. (1995) isolated taxol from endophytic fungi (Taxomyces andreanae, Pestalotiopsis microspora) of the same plant. Rizzo et al. (1997) showed that the endophytic fungi of Baccharis species and not the plant are responsible for the production of roridins and verrucarins causing toxic effects in livestock.

For the Argentinean medicinal plant Erythrina crista-galli anti-inflammatory (Miño et al., 2002) and antibacterial (Mitscher et al., 1988) activities have been described. E. crista-galli can be found in the tropical and subtropical regions of America and it is commonly used as an ornamental plant. In Argentina the wood is used in infusions or decoctions as astringent, narcotic, and sedative (Toursarkissian, 1980). In the course of our studies on endophytes of medicinal plants we found that the majority of the fungi isolated so far from different collections of E. crista-galli belongs to the genus Phomopsis. This genus comprises more than 400 different species widely distributed as pathogens, endophytes or even symbionts of plants (Uecker, 1988). In our investigation of a possible contribution of fungal metabolites to the pharmacological activities of the plant a screening of Phomopsis isolates resulted in the identification of eight known and several new metabolites. Re- 
cently phomol, a polyketide lactone with interesting anti-inflammatory activities in vivo has been described (Weber et al., 2004). Here we describe the taxonomy of 12 Phomopsis strains, their fermentation, and the isolation, biological activities and structure elucidation of several new metabolites.

\section{Materials and Methods}

\section{Producing organisms}

All Phomopsis strains were isolated from leaves and dead or living twigs of Erythrina crista-galli. The plant material was collected in Argentina (Table I). It was cut and surface-sterilized by immersion in $70 \%$ ethanol for $1 \mathrm{~min}, 5 \% \mathrm{NaOCl}$ for $3 \mathrm{~min}$ and $70 \%$ ethanol for $30 \mathrm{~s}$, followed by a wash in sterile distilled water. Samples were then cut into small fragments and plated onto $2 \%$ malt agar with penicillin $G$ and streptomycin sulfate (each $200 \mathrm{mg} / \mathrm{l}$ ). The mycelial cultures are deposited in the culture collection of the Institute of Biotechnology and Drug Research (IBWF), Kaiserslautern, Germany.

\section{Taxonomy}

The different fungal isolates showed all characteristics of the genus Phomopsis. The species, however, could not be unequivocally determined. On YMG agar the strains form dark pycnidial conidiomata, in which both $\alpha$ - and $\beta$-conidia are produced. The $\alpha$-conidia are hyaline, nonseptate, and elliptic while the $\beta$-conidia are hyaline, nonseptate, filiform, and curved. The methods for DNA extraction and ITS amplification have been described by Köpcke et al. (2002). The primers used for amplification were ITS5 (5'-GGAAGTAAAAGTCGTAACAAGG) and ITS4 (5'TCCTCCGCTTATTGATATGC) according to White et al. (1990). Their method was used with slight modifications: A GeneAmp PCR System 9700 was employed (Applied Biosystem, Foster City, CA, USA). The PCR amplification cycle consisted of $30 \mathrm{~s}$ at $94{ }^{\circ} \mathrm{C}, 1 \mathrm{~min}$ at $50{ }^{\circ} \mathrm{C}$, and $1 \mathrm{~min}$ at $72{ }^{\circ} \mathrm{C}$. PCR products were sequenced by $\mathrm{MWG}$ Biotech (Ebersberg, Germany) using the same primers as for the amplification. Each sequence was obtained in duplicate from each of two separate PCR amplifications. Database searches were performed with the FASTA function of the GCG Wisconsin Package.

\section{Fermentation}

Fungi were grown in different media: YMG (4 g yeast extract, $10 \mathrm{~g}$ glucose, $10 \mathrm{~g}$ malt extract/1; pH 5.5); KGA (4 g dried mashed potatoes, $20 \mathrm{~g}$ glucose/l; pH 5.5); Czapek-Dox (2 $\mathrm{g} \mathrm{NaNO}_{3}, 1 \mathrm{~g}$ $\mathrm{K}_{2} \mathrm{HPO}_{4}, 0.5 \mathrm{~g} \mathrm{MgSO} \cdot 7 \mathrm{H}_{2} \mathrm{O}, 0.5 \mathrm{~g} \mathrm{KCl}, 0.01 \mathrm{~g}$ $\mathrm{FeSO}_{4}, 30 \mathrm{~g}$ sucrose/1 $\mathrm{H}_{2} \mathrm{O}_{\text {deion.; }}$ pH 6.3); corn meal ( $10 \mathrm{~g}$ corn meal, $10 \mathrm{~g}$ glucose, $1.5 \mathrm{~g} \mathrm{~K}_{2} \mathrm{HPO}_{4}, 0.5 \mathrm{~g}$ $\mathrm{KCl}, 0.5 \mathrm{~g} \mathrm{NaNO}_{3}, 0.5 \mathrm{~g} \mathrm{MgSO}_{4} \cdot 7 \mathrm{H}_{2} \mathrm{O} / \mathrm{l} ; \mathrm{pH} 5.8$ ); double malt (40 g malt extract/1; $\mathrm{pH} 5.5$ ).

For screening purposes fungi were grown at room temperature in 21 Erlenmeyer flasks containing 11 of medium on a rotary shaker (120 rpm). 5-10 pieces of mycelium from well-grown agar plates were used as inoculum. When the glucose was completely used up and the $\mathrm{pH}$ started to rise to values above 6.0, the culture fluid was separated from the mycelium by filtration. The culture broth was extracted with EtOAc, the organic phase dried with $\mathrm{Na}_{2} \mathrm{SO}_{4}$, concentrated in vacuo and the residue dissolved in $\mathrm{MeOH}$.

Fermentations were carried out in a Biolafitte C6 fermentor containing 201 of medium with aeration (3 1 air/min) and stirring $(120 \mathrm{rpm})$ at room temperature. A well-grown culture $(250 \mathrm{ml})$ in a $500 \mathrm{ml}$ Erlenmeyer flask (grown at room temperature and $120 \mathrm{rpm}$ ) in the same medium was used as inoculum. The culture fluid was separated from the mycelium by filtration. The culture broth was either extracted with EtOAc and the organic phase dried with $\mathrm{Na}_{2} \mathrm{SO}_{4}$ and concentrated in vacuo or passed through a HP21 column [elution of the metabolites with $\mathrm{H}_{2} \mathrm{O} / \mathrm{MeOH}(1: 1), \mathrm{MeOH}$, then acetone].

\section{Isolation of the compounds}

The crude extracts were applied onto a column containing silica gel (Merck 60, 0.063-0.2 mm) and eluted with cyclohexane, cyclohexane/ethylacetate $(9: 1,3: 1,1: 1 \mathrm{v} / \mathrm{v})$, ethylacetate, ethylacetate/methanol $(3: 1,1: 1 \mathrm{v} / \mathrm{v})$ and methanol. For analytical HPLC (HP 1090 Series U, Hewlett-Packard, Waldbronn) a RP-18 column (LiChrospher, $5 \mu \mathrm{m}$ particle size, $125 \times 4 \mathrm{~mm}$, Merck, Darmstadt) was used (flow: $1.5 \mathrm{ml} / \mathrm{min}$; gradient: $\mathrm{H}_{2} \mathrm{O} / \mathrm{methanol}$ $0-70 \%$ in $20 \mathrm{~min}, 70-100 \%$ in $10 \mathrm{~min}$ ). For preparative HPLC a Jasco Model PU-1586 with a Multiwavelength-Detector MD-910 was used (column: Phenomenex, Luna RP 18, $10 \mu \mathrm{m} ; 250 \times$ $21 \mathrm{~mm}$; gradients: $\mathrm{H}_{2} \mathrm{O} /$ methanol; flow: $10 \mathrm{ml} /$ $\min )$. 
Fermentation of Phomopsis sp. E01094 and isolation of phomopyronol (1)

The strain E01094 was cultivated in 201 of Czapek-Dox medium. After $11 \mathrm{~d}$ of fermentation the mycelium was separated from the culture broth and the culture fluid passed through a column $(30 \times 5.5 \mathrm{~cm})$ containing Mitsubishi Diaion HP21 adsorber resin. Elution with $\mathrm{H}_{2} \mathrm{O}$ /acetone (1:1) yielded $569 \mathrm{mg}$ of crude extract. This was applied onto a column $(2.5 \times 10 \mathrm{~cm})$ containing silica gel 60 (Merck). An enriched product (65 mg) was obtained after elution with $100 \% \mathrm{MeOH}$. Preparative HPLC (see above) yielded $27 \mathrm{mg}$ of 1 (Fig. 1) eluting at $41 \% \mathrm{MeOH}$.

\section{Fermentation of Phomopsis sp. E01105 and isolation of compounds $\mathbf{2}$ and $\mathbf{3}$}

Fermentations of Phomopsis sp. E01105 were carried out in 201 fermentors containing CzapekDox medium. After $9 \mathrm{~d}$ the fermentation was stopped and the culture fluid was extracted by passing it through a column containing HP21. The crude product $(125 \mathrm{mg})$ of the first fraction $\left(\mathrm{H}_{2} \mathrm{O} /\right.$ $\mathrm{MeOH}, 1: 1)$ was separated by silica gel chromatography (see above). An enriched product $(46 \mathrm{mg})$ was obtained after elution with 100\% ethylacetate. Preparative HPLC (see above) yielded $9 \mathrm{mg}$ of $\mathbf{3}$ (Fig. 1) eluting at $25 \% \mathrm{MeOH}$. From the second fraction of the HP21 column (100\% $\mathrm{MeOH} ; 478 \mathrm{mg})$, an intermediate product (73 mg) was obtained by silica gel chromatography (see above) and elution with cyclohexane/ethylacetate (1:1). Preparative HPLC (see above) yielded $25 \mathrm{mg}$ of 2 (Fig. 1) eluting at 32\% MeOH.

\section{Fermentation of Phomopsis sp. E02011 and isolation of compounds 4, 5, 6, 7 and 8}

Phomopsis sp. E02011 was grown in 201 of YMG medium. After consumption of the carbon source, the fermentation was stopped and the culture filtrate was extracted with ethylacetate. After evaporation of the organic solvent $1.4 \mathrm{~g}$ of crude extract were obtained. This was applied onto a column $(2.5 \times 10 \mathrm{~cm})$ containing silica gel 60 (Merck) and fractionated into four fractions by elution with cyclohexane/ethylacetate 3:1 (F1), cyclohexane/ ethylacetate 1:1 (F2), ethylacetate (F3) and $\mathrm{MeOH}(\mathrm{F} 4)$. F1 (237 mg) was subjected to preparative HPLC (see above) yielding $143 \mathrm{mg}$ of 4 (Fig. 1) eluting at $55 \% \mathrm{MeOH}$.
F2 (327 mg) was purified by preparative HPLC (see above) yielding $33 \mathrm{mg}$ of $\mathbf{5}$ (Fig. 1) eluting at $31 \% \mathrm{MeOH}, 60 \mathrm{mg}$ of 6 eluting with $53 \% \mathrm{MeOH}$, $57 \mathrm{mg}$ of 7 eluting with $61 \% \mathrm{MeOH}$, and $30 \mathrm{mg}$ of 8 eluting with $65 \% \mathrm{MeOH}$.

Clavatol (9), 4-hydroxymellein (10), mellein (11), mevalonolactone (12), mevinic acid (13), nectriapyrone (14), phomol (15), scytalone (16), tyrosol (17) (Fig. 2)

Known compounds were detected and identified by HPLC-DAD-MS (HP-LC/MSD-System Series 1100, Hewlett Packard) with a LiChroCART Supersphere $100 \mathrm{RP}-18$ column $(125 \times 2 \mathrm{~mm} ; 4 \mu \mathrm{m}$ particle size). A gradient $\mathrm{H}_{2} \mathrm{O}$ /acetonitrile 0 $100 \%$ in $20 \mathrm{~min}$ at a flow rate of $0.8 \mathrm{ml} / \mathrm{min}$ was applied. Retention times [min]: Clavatol, 10.9; 4hydroxymellein, 6.67; mellein, 9.1; mevalonolactone, 2.9; mevinic acid, 14.0; nectriapyrone, 9.4; phomol, 13,3; scytalone, 6.7; tyrosol, 4.2.

\section{Spectroscopic characterization of the isolated compounds}

${ }^{1} \mathrm{H}$ NMR (500 MHz) and ${ }^{13} \mathrm{C}$ NMR (125 MHz) spectra were recorded at room temperature with a Bruker DRX500 spectrometer with an inverse multinuclear $5 \mathrm{~mm}$ probe head equipped with a shielded gradient coil. The spectra were recorded in $\mathrm{CDCl}_{3}$, and the solvent signals (7.26 and $77.0 \mathrm{ppm}$, respectively) were used as reference. The chemical shifts $(\delta)$ are given in ppm, and the coupling constants $(J)$ in Hz. COSY, HMQC and HMBC experiments were recorded with gradient enhancements using sine shaped gradient pulses. For the 2D heteronuclear correlation spectroscopy the refocusing delays were optimised for ${ }^{1} J_{\mathrm{CH}}=$ $145 \mathrm{~Hz}$ and ${ }^{\mathrm{n}} J_{\mathrm{CH}}=10 \mathrm{~Hz}$. The raw data were transformed and the spectra were evaluated with the standard Bruker XWIN-NMR software (rev. 010101). Mass spectra were recorded with a LC-MS (HP 1100; APCI, positive/negative mode) and a Micromass Q-TOF MICRO instrument (HR electrospray spectra), while the UV and IR spectra were recorded with a Perkin-Elmer $\lambda 16$ and a Bruker IFS 48 spectrometer. The optical rotation was measured with a Perkin-Elmer 141 polarimeter at $22^{\circ} \mathrm{C}$.

Phomopyronol (1): Colourless oil; $[\alpha]_{\mathrm{D}}-11^{\circ}$ $\left(\mathrm{MeOH}, c\right.$ 0.5). - UV $(\mathrm{MeOH}): \lambda_{\max }(\log \varepsilon)=$ $296 \mathrm{~nm}$ (3.46). - IR (KBr): $v=3410,2930,1680$, 1565, 1465, 1250 and $1050 \mathrm{~cm}^{-1}$. ${ }^{1} \mathrm{H}$ NMR 
$\left(500 \mathrm{MHz}, \mathrm{CDCl}_{3}\right): \delta[$ mult., $J(\mathrm{~Hz})]=6.06(\mathrm{~s}, 5-\mathrm{H})$, $3.89\left(\mathrm{~s}, 12-\mathrm{H}_{3}\right), 3.66(\mathrm{~m}, 9-\mathrm{Ha}), 3.62(\mathrm{~m}, 9-\mathrm{Hb}), 2.84$ (hext., $J=7,7-\mathrm{H}), 1.97$ (m, 8-Ha), $1.91\left(\mathrm{~s}, 10-\mathrm{H}_{3}\right)$, $1.77(\mathrm{~m}, 8-\mathrm{Hb}), 1.28\left(\mathrm{~d}, J=7.2,11-\mathrm{H}_{3}\right) .-{ }^{13} \mathrm{C}$ NMR $\left(125 \mathrm{MHz}, \mathrm{CDCl}_{3}\right): \delta=167.4(\mathrm{C}-6), 166.0$ (C-2 and C-4), 101.2 (C-3), 93.6 (C-5), 60.2 (C-9), 56.2 (C-12), 37.2 (C-8), 35.4 (C-7), 18.4 (C-11), 8.4 (C-10). - HRESMS: $213.1102\left(\mathrm{C}_{11} \mathrm{H}_{17} \mathrm{O}_{4}\right.$ requires 213.1127).

3-Phenylpropane-1,2-diol (2): Colourless oil; $[\alpha]_{\mathrm{D}}-46^{\circ}(\mathrm{MeOH}, c 0.3)$. UV $(\mathrm{MeOH}): \lambda_{\max }$ $(\log \varepsilon)=260 \mathrm{~nm}(2.47)$. - IR (KBr): $v=3390$, $2925,1605,1495,1455,1090,1030,745$ and $700 \mathrm{~cm}^{-1}$. - ${ }^{1} \mathrm{H}$ NMR $\left(500 \mathrm{MHz}, \mathrm{CDCl}_{3}\right): \delta[$ mult., $J(\mathrm{~Hz})]=7.32(\mathrm{t}, J=7.5,3-\mathrm{H}$ and $5-\mathrm{H}), 7.25(\mathrm{t}, J=$ $7.5,4-\mathrm{H}), 7.23(\mathrm{~d}, J=7.5,2-\mathrm{H}$ and $6-\mathrm{H}), 3.96(\mathrm{~m}$, $8-\mathrm{H}), 3.70(\mathrm{dd}, J=3.2$ and $11.2,9-\mathrm{Ha}), 3.54(\mathrm{dd}$, $J=6.9$ and $11.2,9-\mathrm{Hb}), 2.81(\mathrm{dd}, J=5.4$ and 13.7 , 7-Ha), 2.77 (dd, $J=8.0$ and 13.7, 7-Hb). $-{ }^{13} \mathrm{C}$ NMR (125 MHz, $\left.\mathrm{CDCl}_{3}\right): \delta=137.7$ (C-1), 129.3 (C-2/C-6), 128.7 (C-3/C-5), 126.6 (C-4), 73.0 (C-8), 66.0 (C-9), 39.8 (C-7). - HRESMS: 153.0929 $\left(\mathrm{C}_{9} \mathrm{H}_{13} \mathrm{O}_{2}\right.$ requires 153.0916).

4-(2,3-Dihydroxypropoxy)benzoic acid (3): Colourless oil; $[\alpha]_{\mathrm{D}}-23^{\circ}(\mathrm{MeOH}, c$ 0.6). - UV $(\mathrm{MeOH}): \lambda_{\max }(\log \varepsilon)=257 \mathrm{~nm}$ (4.27). - IR $(\mathrm{KBr}): v=3435,2930,1690,1610,1515,1445,1290$, $1170,1115,1040,960,850$ and $770 \mathrm{~cm}^{-1} \cdot-{ }^{1} \mathrm{H}$ NMR $\left(500 \mathrm{MHz}, \mathrm{CDCl}_{3}\right): \delta[$ mult., $J(\mathrm{~Hz})]=7.86$ $(\mathrm{m}, 3-\mathrm{H}$ and $5-\mathrm{H}), 6.78(\mathrm{~m}, 2-\mathrm{H}$ and $6-\mathrm{H}), 4.26(\mathrm{~m}$, 8- $\left.\mathrm{H}_{2}\right), 3.94(\mathrm{~m}, 9-\mathrm{H}), 3.65(\mathrm{~m}, 10-\mathrm{Ha}), 3.57$ (dd, $J=5.9$ and $11.6,10-\mathrm{Hb}) .-{ }^{13} \mathrm{C} \mathrm{NMR}(125 \mathrm{MHz}$, $\left.\mathrm{CDCl}_{3}\right): \delta=167.0(\mathrm{C}-1), 161.7$ (C-7), 131.8 (C-3/ C-5), 120.7 (C-4), 115.5 (C-2/C-6), 70.1 (C-9), 65.2 (C-8), 63.2 (C-10). - HRESMS: 213.0755 $\left(\mathrm{C}_{10} \mathrm{H}_{13} \mathrm{O}_{5}\right.$ requires 213.0763).

2-(Hydroxymethyl)-3-propylphenol (4): Colourless oil. - UV (MeOH): $\lambda_{\max }(\log \varepsilon)=279 \mathrm{~nm}$ (3.81). - IR (KBr): $v=3345,2960,1590,1465$, 1340, 1285, 1185, 990, 785 and $750 \mathrm{~cm}^{-1} .-{ }^{1} \mathrm{H}$ NMR $\left(500 \mathrm{MHz}, \mathrm{CDCl}_{3}\right): \delta[$ mult., $J(\mathrm{~Hz})]=7.11$ $(\mathrm{t}, J=8.0,5-\mathrm{H}), 6.74(\mathrm{~d}, J=8.0,6-\mathrm{H}), 6.72(\mathrm{~d}, J=$ $8.0,4-\mathrm{H}), 4.92\left(\mathrm{~s}, 7-\mathrm{H}_{2}\right), 2.56\left(\mathrm{t}, J=7.7,8-\mathrm{H}_{2}\right), 1.54$ $\left(\mathrm{m}, 9-\mathrm{H}_{2}\right), 0.96\left(\mathrm{t}, J=7.4,10-\mathrm{H}_{3}\right) .-{ }^{13} \mathrm{C}$ NMR $\left(125 \mathrm{MHz}, \mathrm{CDCl}_{3}\right): \delta=156.6(\mathrm{C}-1), 140.9(\mathrm{C}-3)$, 128.8 (C-5), 122.7 (C-2), 121.6 (C-4), 114.4 (C-6), 60.0 (C-7), 35.2 (C-8), 24.8 (C-9), 14.0 (C-10). HRESMS: $167.1059\left(\mathrm{C}_{10} \mathrm{H}_{15} \mathrm{O}_{2}\right.$ requires 167.1072).

2-(Hydroxymethyl)-3-(1-hydroxypropyl)phenol (5): Colourless oil; $[\alpha]_{\mathrm{D}}-26^{\circ}(\mathrm{MeOH}, c$ 0.9). UV (MeOH): $\lambda_{\max }(\log \varepsilon)=280 \mathrm{~nm}(3.35)$. - IR $(\mathrm{KBr}): v=3380,2965,1590,1465,1270,995,875$,
795 and $750 \mathrm{~cm}^{-1} .-{ }^{1} \mathrm{H}$ NMR (500 $\left.\mathrm{MHz}, \mathrm{CDCl}_{3}\right)$ : $\delta[$ mult., $J(\mathrm{~Hz})]=7.16(\mathrm{t}, J=7.9,5-\mathrm{H}), 6.97(\mathrm{~d}, J=$ $7.9,6-\mathrm{H}), 6.78(\mathrm{~d} J=7.9,4-\mathrm{H}), 4.90(\mathrm{~d}, J=12.9$, 7-Ha), 4.83 (d, $J=12.9,7-\mathrm{Hb}), 4.68(\mathrm{t}, J=7.0$, 8-H), 1.78 (m, 9-Ha), $1.74(\mathrm{~m}, 9-\mathrm{Hb}), 0.92(\mathrm{t}, J=$ 7.3, $\left.10-\mathrm{H}_{3}\right) .-{ }^{13} \mathrm{C}$ NMR $\left(125 \mathrm{MHz}, \mathrm{CDCl}_{3}\right): \delta=$ 156.7 (C-1), 142.5 (C-3), 129.1 (C-5), 123.2 (C-2), 118.2 (C-4), 115.9 (C-6), 73.2 (C-8), 58.3 (C-7), 30.8 (C-9), 10.5 (C-10). - HRESMS: 205.0837 $\left(\mathrm{C}_{10} \mathrm{H}_{14} \mathrm{O}_{3} \mathrm{Na}\right.$ requires 205.0841).

Compound 6: Colourless oil; $[\alpha]_{\mathrm{D}}+70^{\circ}(\mathrm{MeOH}$, c 0.8). - UV $(\mathrm{MeOH}): \lambda_{\max }(\log \varepsilon)=216 \mathrm{~nm}$ (3.89). - IR (KBr): $v=3440,2935,1705,1675$, $1460,1250,1200,1165,1080,1005$ and $870 \mathrm{~cm}^{-1}$. ${ }^{1} \mathrm{H}$ NMR $\left(500 \mathrm{MHz}, \mathrm{CDCl}_{3}\right): \delta[$ mult., $J(\mathrm{~Hz})]=$ $6.96(\mathrm{dd}, J=5.7$ and 9.9, 3-H), $6.04(\mathrm{~d}, J=9.9$, 2-H), 5.11 (m, 13-H), 4.30 (m, 4-H), 2.82 (m, 5-H), $2.68\left(\mathrm{~m}, 6-\mathrm{H}\right.$ and $\left.7-\mathrm{H}_{2}\right), 2.17(\mathrm{~m}, 9-\mathrm{Ha}), 2.09(\mathrm{~m}$, 12-Ha), 1.81 (m, 11-Ha), 1.64 (m, 10-Ha), 1.37 (m, $12-\mathrm{Hb}), 1.31(\mathrm{~m}, 10-\mathrm{Hb}$ and $11-\mathrm{Hb}), 1.27(\mathrm{~d}, J=$ $\left.6.7, \quad 14-\mathrm{H}_{3}\right), \quad 1.19(\mathrm{~m}, \quad 9-\mathrm{Hb}) . \quad-{ }^{13} \mathrm{C}$ NMR $\left(125 \mathrm{MHz} \mathrm{CDCl}_{3}\right): \delta=199.8(\mathrm{C}-1), 171.6(\mathrm{C}-8)$, 145.9 (C-3), 130.7 (C-2), 73.4 (C-13), 67.0 (C-4), 45.8 (C-6), 38.6 (C-7), 36.8 (C-5), 30.2 (C-12), 22.8 (C-9), 22.7 (C-11), 22.2 (C-10), 18.4 (C-14). HRESMS: $253.1401\left(\mathrm{C}_{14} \mathrm{H}_{21} \mathrm{O}_{4}\right.$ requires 253.1440). 8-(Hydroxymethyl)-2,2-dimethyl-7-propylchroman-3-ol (7): Colourless oil; $[\alpha]_{\mathrm{D}}+17^{\circ}(\mathrm{MeOH}, c$ 0.5). - UV (MeOH): $\lambda_{\max }(\log \varepsilon)=283 \mathrm{~nm}$ (3.54). - IR (KBr): $v=3400,2960,1580,1380$, 1260, 1065 and $995 \mathrm{~cm}^{-1}$. - ${ }^{1} \mathrm{H}$ NMR $(500 \mathrm{MHz}$, $\left.\mathrm{CDCl}_{3}\right): \delta[$ mult., $J(\mathrm{~Hz})] 6.91(\mathrm{~d}, J=7.7,5-\mathrm{H}), 6.69$ $(\mathrm{d}, J=7.7,6-\mathrm{H}), 4.81(\mathrm{~s}, 9-\mathrm{H} 2), 3.52$ (d, $J=10.0$, 3-H), $2.77(\mathrm{dd}, J=10.0$ and 14.3, 4-Ha), $2.61(\mathrm{~d}$, $J=14.3,4-\mathrm{Hb}), 2.58\left(\mathrm{~m}, 10-\mathrm{H}_{2}\right), 1.55$ (hext., $J=7$, $\left.11-\mathrm{H}_{2}\right), 1.27\left(\mathrm{~s}, 13-\mathrm{H}_{3}\right), 1.24\left(\mathrm{~s}, 14-\mathrm{H}_{3}\right), 0.96(\mathrm{t}, J=$ 7.3, 12- $\left.\mathrm{H}_{3}\right) .-{ }^{13} \mathrm{C} \mathrm{NMR}\left(125 \mathrm{MHz}, \mathrm{CDCl}_{3}\right): \delta=$ 154.8 (C-8a), 140.3 (C-7), 130.2 (C-5), 125.2 (C-8), 123.9 (C-4a), 121.6 (C-6), 80.6 (C-3), 73.1 (C-2), 59.0 (C-9), 35.2 (C-10), 33.7 (C-4), 26.2 (C-13), 24.9 (C-11), 23.0 (C-14), 14.0 (C-12). - HRESMS: $251.1642\left(\mathrm{C}_{15} \mathrm{H}_{23} \mathrm{O}_{3}\right.$ requires 251.1647$)$.

(4E,10E)-Trideca-4,10,12-triene-2,8-diol (8): Colourless oil; $[\alpha]_{\mathrm{D}}-12^{\circ}(\mathrm{MeOH}, c \quad 0.5)$. - UV $(\mathrm{MeOH}): \lambda_{\max }(\log \varepsilon)=225 \mathrm{~nm}$ (4.12). - IR (KBr): $v=3410,2925,1650,1450,1075,1005,970$ and $900 \mathrm{~cm}^{-1}$. - ${ }^{1} \mathrm{H}$ NMR $\left(500 \mathrm{MHz}, \mathrm{CDCl}_{3}\right)$ : $\delta[$ mult., $J(\mathrm{~Hz})]=6.33(\mathrm{ddd}, J=10.1,10.5$ and $17.0,12-\mathrm{H}), 6.14(\mathrm{dd}, J=10.5$ and $15.2,11-\mathrm{H}), 5.70$ $(\mathrm{dt}, J=15.2$ and $7.4,10-\mathrm{H}), 5.57(\mathrm{dt}, J=15.7$ and 6.1, 5-H), $5.48(\mathrm{dt}, J=15.7$ and $7.4,4-\mathrm{H}), 5.15(\mathrm{~d}$, $J=17.0,13-\mathrm{Ha}), 5.03(\mathrm{~d}, J=10.1,13-\mathrm{Hb}), 3.80$ 
(hept., $J=6.0,2-\mathrm{H}), 3.68$ (m, 8-H), 2.32 (m, 9-Ha), 2.21 (m, 3-Ha), 2.20 (m, 9-Hb), 2.14 (m, 6- $\mathrm{H}_{2}$ ), 2.08 $(\mathrm{m}, 3-\mathrm{Hb}), 1.56\left(\mathrm{~m}, 7-\mathrm{H}_{2}\right), 1.19\left(\mathrm{~d}, J=6.2,1-\mathrm{H}_{3}\right)$. ${ }^{13} \mathrm{C}$ NMR $\left(125 \mathrm{MHz}, \mathrm{CDCl}_{3}\right): \delta=136.7(\mathrm{C}-12)$, 134.2 (C-11), 133.8 (C-5), 130.3 (C-10), 126.5 (C-4), 116.0 (C-13), 70.7 (C-8), 67.2 (C-2), 42.4 (C-3), 40.7 (C-9), 36.4 (C-7), 29.0 (C-6), 22.7 (C-1). - HRESMS: $233.1496\left(\mathrm{C}_{13} \mathrm{H}_{22} \mathrm{O}_{2} \mathrm{Na}\right.$ requires 233.1517).

\section{Biological assays}

Antimicrobial activities were determined in the serial dilution assay as described previously (Anke et al., 1989). Inhibition of growth of germinated seeds of Setaria italica and Lepidium sativum was tested according to Anke et al. (1989). Nematicidal activity was measured as described by Stadler et al. (1994).

Cytotoxic activity was assayed as described previously (Zapf et al., 1995) with slight modifications. L1210 (ATCC CCI 219) and Colo-320 cells (DSMZ ACC144) were grown in RPMI 1640 medium (GIBCO, BRL), MDA-MB-231 (ATCC HTB26) cells in D-MEM (GIBCO, BRL), supplemented with $10 \%$ fetal calf serum (FCS) (GIBCO, BRL), $65 \mu \mathrm{g} / \mathrm{ml}$ of penicillin $\mathrm{G}$ and $100 \mu \mathrm{g} / \mathrm{ml}$ of streptomycin sulfate. The assays contained $1 \times 10^{5}$ cells/ml medium.

Reporter gene assays: The STAT1/STAT2 dependent signal transduction was tested in HeLaS3 cells (ATCC CCL2.2). The reporter plasmid pGE3-GAS/ISRE contained five copies of a GAS/ ISRE consensus oligonucleotide immediately upstream of the thymidine kinase promoter driven SEAP reporter gene (Erkel et al., 1996). The TNF$\alpha$ promotor-driven luciferase reporter plasmid pJR-TNF-pro was tested in Jurkat cells (ATCC TIB 152) as described by Weidler et al. (2000). The assay using the NF- $\varkappa \mathrm{B}$ promotor-driven luciferase reporter plasmid pNF $\varkappa B-L u c$ (Stratagene) in Jurkat cells was performed as described for the TNF- $\alpha$ reporter gene assay with minor modifications: The cells were electroporated with $30 \mu \mathrm{g}$ of the $\mathrm{pNF} \varkappa \mathrm{B}-\mathrm{Luc}$ vector. After electroporation the cells were seeded in 24 -well plates $\left(5 \times 10^{7}-1 \times\right.$ $10^{8}$ cells $/ \mathrm{ml}$ in OPTIMEM medium containing $10 \%$ of fetal calf serum). The activity of the luciferase was determined $24 \mathrm{~h}$ after transfection using the Luciferase Assay System (Promega, Mannheim) according to the manufacturer's instructions with a luminometer.
Mouse ear edemas were induced with TPA according to Carlson et al. (1985) and De Young et al. (1989). The assay was performed as described before (Weber et al., 2004). Male Swiss mice (25$30 \mathrm{~g}$ ) were used in groups of 10 animals each. The right ear of each mouse received $2.5 \mu \mathrm{g}$ of $12-\mathrm{O}-$ tetradecanoylphorbol-13-acetate (TPA) by topical application as $0.125 \mu \mathrm{g} / \mu \mathrm{l}$ acetone solution $(10 \mu \mathrm{l}$ to each side of the ear). Compounds dissolved in acetone were applied topically immediately after TPA at a dose of $1 \mathrm{mg} / \mathrm{ear}$. The left ear, used as a control, received only the vehicle. Indomethacin, an inhibitor of prostaglandin synthesis, was used as reference drug $(0.5 \mathrm{mg} / \mathrm{ear})$. After $4 \mathrm{~h}$, the animals were killed and disks of $6 \mathrm{~mm}$ diameter were removed from each ear and weighted. The swelling was measured as the difference in weight between the punches from the right and left ears.

\section{Results and Discussion}

\section{Isolation and identification of endophytic fungi}

The Phomopsis strains were isolated from fresh leaves and twigs as well as from dead plant material. Phomopsis spp. were isolated from all Erythrina crista-galli trees although the plant material was collected in different places and during different seasons (Table I). All twelve isolates develop black pycnidia on YMG agar. Within these pycnidia, $\alpha$ - and $\beta$-conidia are produced. A comparison of the ribosomal RNA genes is commonly used for the phylogenetic analysis of related species (Köpcke et al., 2002). Therefore the ITS sequences of seven Phomopsis strains were analyzed and compared to one of the strains (E01094) taken as a reference (Table II). The alignment of the ITS sequences showed that the sequences of E01094 and E02089 are identical. Since isolates with one to three base pair differences are considered to belong to the same species (Pfunder et al., 2001) this is true for five strains, E01094, E02018, E02074, E02084, and E02089. Strain E02011 apparently belongs to another species. A FASTA search was performed for the strains E01094, E01105, and E02011. E01094 and E01105 have a sequence identity of $98.7 \%$ (8 differences) or $98.0 \%$ (10 differences) with Phomopsis sp. GJS83-377 (AF 102999). Strain E02011 has a sequence identity of $95.6 \%$ (26 differences) with $\mathrm{Di}$ aporthe caulivola 713. Phomopsis is the asexual stage of Diaporthe. 
Table I. Endophytic fungi isolated from Erythrina crista-galli.

\begin{tabular}{llll}
\hline Strain & Plant organ & Origin & Date \\
\hline E01094 & Dead twig & Rio Capitan (tributary of the Parana) & Sept. 8, 2001 \\
E0105 & Green twig & Rio Capitan (tributary of the Parana) & Sept. 8, 2001 \\
E02001 & Leaves & Chivilcoy & Oct. 1, 2002 \\
E02003 & Green twig & Chivilcoy & Oct. 1, 2002 \\
E02004 & Dead twig & Chivilcoy & Oct. 1, 2002 \\
E02005 & Dead twig & Chivilcoy & Oct. 1, 2002 \\
E02011 & Dead twig & Parana-Delta & Oct. 1, 2002 \\
E02018 & Dead twig & Boraso-Delta & Oct. 1, 2002 \\
E02069 & Young twig & Campus of the University of Buenos Aires at the & Dec. 3, 2002 \\
E02074 & Young twig & Rio de la Plata & Ruta Provincial 25 2002 \\
E02084 & Young twig & Country road from Parana de las Palmas, 2 km & Dec. 4, 2002 \\
E02089 & Young twig & Rio Papitan (tributary of the Parana) & Dec. 5, 2002 \\
\hline
\end{tabular}

Table II. Differences in the ITS sequences compared with the reference strain E01094.

\begin{tabular}{ll}
\hline Strain & \multicolumn{1}{c}{ Differences in the ITS sequences } \\
\hline E01094 & Reference \\
E01105 & 4 substitutions \\
E02011 & 36 substitutions, 9 insertions, 1 deletion \\
E02018 & 1 deletion (T at position 543) \\
E02074 & 3 substitutions \\
E02084 & 2 substitutions \\
E02089 & - \\
\hline
\end{tabular}

- , No differences.

\section{Isolation and structure determination}

Phomopyronol (1)

Phomopyronol (1) (Fig. 1) was isolated from the culture fluid of the Phomopsis strain E01094 cultivated in 201 Czapek-Dox medium, as described above. $\mathbf{1}$ is a new compound, and it is structurally related to the phomapyrones reported from the blackleg fungus (Pedras et al., 1994). The structure elucidation of 1 was hampered by the fact that only 10 signals were observed in the ${ }^{13} \mathrm{C}$ NMR spectrum recorded in $\mathrm{CDCl}_{3}$, although high resolution MS experiments revealed that the compound contains 11 carbon atoms. The elemental composition suggested by the mass spectra, $\mathrm{C}_{11} \mathrm{H}_{16} \mathrm{O}_{4}$, gives the unsaturation index 4 , and with three double bonds 1 should also contain one ring. COSY and HMBC correlations clearly revealed the saturated substructure, and HMBC correlations from $11-\mathrm{H}_{3}$ to $\mathrm{C}-6$ and from $7-\mathrm{H}$ to $\mathrm{C}-5$ and C-6 showed that the saturated part is attached to

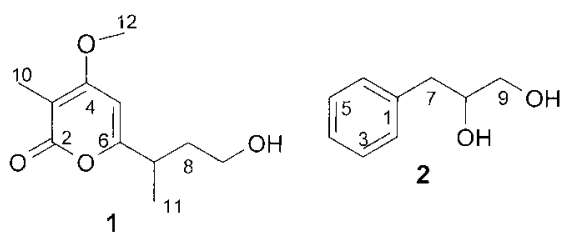<smiles>O=C(O)c1ccc(OCC(O)CO)cc1</smiles><smiles>CCCc1cccc(O)c1C=O</smiles>

4

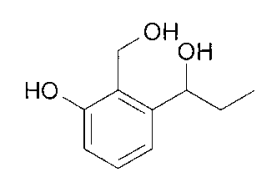

5
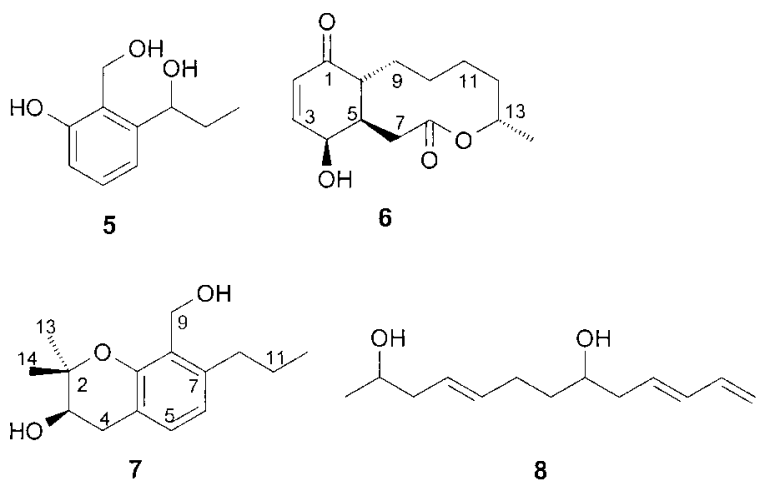

Fig. 1. Structures of phomopyronol (1), 3-phenylpropane-1,2-diol (2), 4-(2,3-dihydroxypropoxy)benzoic acid (3), 2-(hydroxymethyl)-3-propylphenol (4), 2-(hydroxymethyl)-3-(1-hydroxypropyl)phenol (5), compound $\mathbf{6}$, 8-(hydroxymethyl)-2,2-dimethyl-7-propylchroman-3-ol (7), and (4E,10E)-trideca-4,10,12-triene-2,8-diol (8). 
C-6 and indicated that C-5/C-6 is part of a double bond that is polarized by a heteroatom (oxygen) attached to C-6. The methoxy protons gave a strong $\mathrm{HMBC}$ correlation to $\mathrm{C}-4$ and a weak to C-5, and $10-\mathrm{H}_{3}$ correlated to $\mathrm{C}-3$ and $\mathrm{C}-4$, suggesting that the $\mathrm{C}-5 / \mathrm{C}-6$ double bond is conjugated with the C-3/C-4 double bond. With this at hand only one carbon and one oxygen atom remain, and in order to comply with the unsaturation index this must be a carbonyl group in a lactone. C-9 could not be involved in this lactone, the proton shifts of $9-\mathrm{H}_{2}$ were too high, and the only remaining possibility is the proposed pyrone structure. C-2 and C-4 consequently had identical chemicals shifts in $\mathrm{CDCl}_{3}$, and their signal was actually stronger than expected. The overlap of C-2 and C-4 observed has previously been reported for similar 4-hydroxylated and 4-methoxylated pyrones (Pedras et al., 1994).

3-Phenylpropane-1,2-diol (2) and 4-(2,3-dihydroxypropoxy)benzoic acid (3)

The two aromatic compounds $\mathbf{2}$ and $\mathbf{3}$ were isolated from Phomopsis E01105. The compounds were isolated as described above, and their structures determined by spectroscopic techniques. Both are new natural products. For 2 , the presence of a phenyl group was indicated by both ${ }^{1} \mathrm{H}$ and ${ }^{13} \mathrm{C}$ NMR, and COSY and HMBC correlations within the side chain as well as between the side chain and the phenyl group determined the structure. The MS data were in accord with the structure. Compound $\mathbf{3}$ has the elemental composition $\mathrm{C}_{10} \mathrm{H}_{12} \mathrm{O}_{5}$ and has 5 unsaturations, and a para substituted benzene ring with an electron-releasing substituent was indicated by the NMR data. HMBC correlations from $8-\mathrm{H}_{2}$ to $\mathrm{C}-1$ showed that this oxygen atom is present as an ether, and the glycerol moiety was easily established from NMR data. The remaining carboxylic group must be positioned as indicated in Fig. 1, and HMBC correlations from $3-\mathrm{H} / 5-\mathrm{H}$ to $\mathrm{C}-7$ confirmed this.

2-(Hydroxymethyl)-3-propylphenol (4),

2-(hydroxymethyl)-3-(1-hydroxypropyl)phenol (5), compound 6, 8-(hydroxymethyl)-2,2-dimethyl7-propylchroman-3-ol (7) and $(4 E, 10 E)$-trideca4,10,12-triene-2,8-diol (8)

The five compounds were isolated from the culture fluid of Phomopsis sp. E02011 as described above. While compounds 4, 5, 7 and $\mathbf{8}$ are new, compound 6 was recently reported from a Penicillium strain as a bacterial DNA primase inhibitor (Chu et al., 2003). Although the NMR data reported for 6 in $\mathrm{CD}_{3} \mathrm{OD}$ are identical to those obtained by us, the NMR data in $\mathrm{CDCl}_{3}$ recorded in this investigation are given in the experimental part for convenience. NMR data revealed that $\mathbf{4}$ is a 1,2,3-trisubstituted benzene, and HMBC correlations showed that the order of the substituents are hydroxyl, hydroxylmethyl and propyl. $\mathbf{5}$ is an oxidized version of $\mathbf{4}$, and similar NMR experiments showed that the difference between the two is that the propyl group of $\mathbf{4}$ is a 1-hydroxylpropyl group in $\mathbf{5}$. 7 has the composition $\mathrm{C}_{15} \mathrm{H}_{22} \mathrm{O}_{3}$ (with 5 unsaturations) according to high resolution mass spectrometry experiments, it contains the same basic structure as $\mathbf{4}$ but is prenylated and close to a chroman structure. HMBC correlations from the two methyl singlets to $\mathrm{C}-2$ and $\mathrm{C}-3$ showed that the two oxidized carbon atoms are vicinal, and COSY as well as HMBC correlations from $3-\mathrm{H}$ to 4- $\mathrm{H}_{2}$ and $\mathrm{C}-4 \mathrm{a}$ revealed that the oxygen link between $\mathrm{C}-2$ and $\mathrm{C}-8 \mathrm{a}$ closes the second ring. The triene $\mathbf{8}$ is a straight chain without rings, according to the composition suggested by the mass spectra, and both double bonds are $E$. The structure elucidation is straightforward and based on COSY correlations, although the recorded HMBC correlations are perfectly in accord with the suggested structure.

Identification of known compounds from fermentations of the E. crista-galli endophytes

To compare the production of secondary metabolites, all isolates were cultivated in 11 YMG medium in 21 Erlenmeyer flasks. Known compounds were detected and identified with HPLC-DADMS (see Material and Methods). Table III gives an

Table III. Overview of metabolites so far detected in cultures of the endophytic fungi of Erythrina crista-galli.

\begin{tabular}{|c|c|}
\hline Phomopsis sp. & Compounds produced \\
\hline E01094 & $1,9,10,11,14,15,16,17$ \\
\hline E01105 & $2,3,11,12,14,16,17$ \\
\hline E02001 & 11 \\
\hline E02003 & 11 \\
\hline E02004 & 11 \\
\hline E02005 & 11 \\
\hline E02011 & $4,5,6,7,8,11,13,14,17$ \\
\hline E02018 & 11,15 \\
\hline E02069 & 11 \\
\hline E02074 & 11 \\
\hline E02084 & 11, 17 \\
\hline E02089 & $10,11,14$ \\
\hline
\end{tabular}


overview of all metabolites detected in the extracts of the culture broth of the twelve Phomopsis strains of E. crista-galli. Mellein (11) (Fig. 2) was detected in the crude extracts of the culture fluids of all isolates. It has been described from fermentations of Aspergillus melleus (Nishikawa, 1933), Fusarium larvarum (Grove and Pople, 1979), Cercospora taiwanensis (Carmarda et al., 1976) and<smiles>CC(=O)c1cc(C)c(O)c(C)c1O</smiles><smiles>CC1OC(=O)c2c(O)cccc2C1O</smiles><smiles>CC1Cc2cccc(O)c2C(=O)O1</smiles>

11<smiles>CCC(C)C(=O)OC1C[C@H](C)C=C2C=CC(C)C(CCC3CC(O)CC(=O)O3)C21</smiles>

13<smiles>CCCCCC(OC(=O)CC(O)C(O)C=CC(=O)O)C(OC(=O)C(C)=CC(C)CC)C(O)CC</smiles><smiles>O=C1CC(O)Cc2cc(O)cc(O)c21</smiles><smiles>OCCc1ccc(O)cc1</smiles>

Fig. 2. Structures of the known compounds clavatol (9), 4-hydroxymellein (10), mellein (11), mevalonolactone (12), mevinic acid (13), nectriapyrone (14), phomol (15), scytalone (16), and tyrosol (17). many other fungi. The compound has phytotoxic, antibacterial, and antifungal activities (Takeuchi et al., 1992; Wenke, 1993). In the extracts of two strains 4-hydroxymellein (10) was detected. Nectriapyrone (14) and tyrosol (17), both common fungal metabolites, were identified in the crude extracts of four isolates. For nectriapyrone antibacterial activity against Staphylococcus aureus has been described (Nair und Carey, 1975). Tyrosol was isolated by Cross et al. (1963) as a fungal metabolite of Gibberella fujikuroi with phytotoxic activity (Devys et al., 1976). Mellein and nectriapyrone were isolated by Claydon et al. (1985) from Phomopsis oblonga, commonly found on the bark of trees of the genus Ulmus. Trees infected by $P$. oblonga are protected from the attack of insects of the genus Scolytus (bark beetle) (Webber, 1981).

Scytalone (16) and phomol (15) (Weber et al., 2004) were detected in two strains. Scytalone is an intermediate in the biosynthesis of melanin, the dark pigment of many phytopathogenic fungi (Bell and Wheeler, 1986).

Clavatol (9), mevalonolactone (12), and mevinic acid (13) were detected in only one endophyte. Clavatol was first isolated from cultures of Aspergillus clavatus (Hassal and Todd, 1947), but no biological activities have been described. Mevalonic acid is an intermediate in cholesterol biosynthesis. Mevinic acid is an inhibitor of HMG-CoA reductase, the key enzyme of cholesterol biosynthesis (Endo and Hasumi, 1997). Derivatives are used as cholesterol-lowering drugs.

\section{Biological properties}

The antimicrobial activities of the new compounds are shown in Table IV. None of the compounds inhibited the growth of Bacillus brevis, $B$. subtilis, Micrococcus luteus, Mycobacterium phlei, Escherichia coli K12, Ascocyta pisi, Candida glabrata, C. krusei, C. parapsilosis, Fusarium fujikuroi and $F$. oxysporum (MIC $>100 \mu \mathrm{g} / \mathrm{ml}$ ).

Phytotoxic activities towards Setaria italica or Lepidium sativum were observed for 5, 6, 7, and 8 at concentrations of $667 \mu \mathrm{g} / \mathrm{ml}$ (Table V). No nematicidal activities were observed at concentrations up to $100 \mu \mathrm{g} / \mathrm{ml}$ against Meloidogyne incognita and Caenorhabditis elegans (data not shown). Cytotoxic activities were tested up to a concentration of $100 \mu \mathrm{g} / \mathrm{ml}$. Only compound 6, showed significant $(>50 \mu \mathrm{g} / \mathrm{ml})$ cytotoxic activities against 
Table IV. Antimicrobial activities of compounds $\mathbf{1 - 8}$ in the serial dilution assay.

\begin{tabular}{|c|c|c|c|c|c|c|c|}
\hline \multirow[t]{3}{*}{ Organism } & \multicolumn{7}{|c|}{ Minimal inhibitory concentration $[\mu \mathrm{g} / \mathrm{ml}]$} \\
\hline & & & & ompou & & & $\mathbf{9}$ \\
\hline & & & & & & & \\
\hline \multicolumn{8}{|l|}{ Bacteria* $^{*}$} \\
\hline Arthrobacter citreus & $100 \mathrm{~s}$ & $-*$ & - & - & $50 \mathrm{~s}$ & - & - \\
\hline Corynebacterium insidiosum & $50 \mathrm{~s}$ & - & - & - & $50 \mathrm{~s}$ & - & - \\
\hline Enterobacter dissolvens & $50 \mathrm{~s}$ & - & - & - & - & - & - \\
\hline \multirow{2}{*}{\multicolumn{8}{|c|}{ Yeasts** }} \\
\hline & & & & & & & \\
\hline Nematospora coryli & $100 \mathrm{~s}$ & - & - & - & $50 \mathrm{z}$ & - & $50 z$ \\
\hline Schizosaccharomyces octospora & - & - & - & - & $100 \mathrm{z}$ & - & - \\
\hline Sporobolomyces roseus & - & $100 \mathrm{~s}$ & - & $100 \mathrm{~s}$ & $20 z$ & - & $100 z$ \\
\hline \multicolumn{8}{|l|}{ Fungi** } \\
\hline Absidia glauca + & $50 \mathrm{~s}$ & $50 \mathrm{~s}$ & $10 \mathrm{z}$ & $50 \mathrm{z}$ & $10 \mathrm{z}$ & - & $50 \mathrm{z}$ \\
\hline Absidia glauca - & $50 \mathrm{~s}$ & 10 & $50 \mathrm{~s}$ & $50 \mathrm{z}$ & $20 \mathrm{z}$ & $50 \mathrm{z}$ & $50 z$ \\
\hline Aspergillus ochraceus & - & - & - & $100 z$ & $100 z$ & - & - \\
\hline Paecilomyces variotii & $10 \mathrm{~s}$ & - & - & - & $50 \mathrm{~s}$ & - & $50 \mathrm{~s}$ \\
\hline Penicillium islandicum & - & - & - & - & $100 \mathrm{z}$ & - & $50 \mathrm{~s}$ \\
\hline Penicillium notatum & $100 \mathrm{~s}$ & - & - & - & $5 \mathrm{~s}$ & - & - \\
\hline Zygorhynchus moelleri & $100 \mathrm{~s}$ & - & - & - & $100 z$ & - & - \\
\hline
\end{tabular}

* Nutrient broth (Difco).

** YMG-medium.

,- MIC $>100 \mu \mathrm{g} / \mathrm{ml}$.

$\mathrm{z}$, bactericidal/fungicidal.

s, bacteriostatic/fungistatic.

Table V. Phytotoxic activities against Lepidium sativum and Setaria italica at a concentration of $667 \mu \mathrm{g} / \mathrm{ml}$.

\begin{tabular}{lcc}
\hline Compound & \multicolumn{2}{c}{ Inhibition of } \\
& Lepidium sativum $(\%)$ & Setaria italica $(\%)$ \\
\hline $\mathbf{1}$ & 50 & $-{ }^{*}$ \\
$\mathbf{2}$ & - & - \\
$\mathbf{3}$ & - & - \\
$\mathbf{4}$ & 4 & 9 \\
$\mathbf{5}$ & 50 & 50 \\
$\mathbf{6}$ & 100 & 15 \\
$\mathbf{7}$ & 60 & 70 \\
$\mathbf{8}$ & 10 & 34 \\
\hline
\end{tabular}

*No inhibition.
$\mathrm{L} 1210\left(\mathrm{IC}_{50} 1 \mu \mathrm{g} / \mathrm{ml}\right)$, Colo-320 ( $\left.\mathrm{IC}_{50} 1 \mu \mathrm{g} / \mathrm{ml}\right)$, and MDA-MB-231 ( $\left.\mathrm{IC}_{50} 5 \mu \mathrm{g} / \mathrm{ml}\right)$.

The transcription factors NFxB, STAT1/STAT2 and the cytokine TNF- $\alpha$ are key players in inflammation. The STAT1/STAT2 dependent signal transduction was tested in HeLa-S3 cells with a reporter plasmid containing five copies of a GAS/ ISRE consensus oligonucleotide as described in Materials and Methods. The TNF- $\alpha$ promotor activity and $\mathrm{NF} x \mathrm{~B}$ dependent transcription were assayed in Jurkat cells as described above. At concentrations of 20 and $50 \mu \mathrm{g} / \mathrm{ml}$ no effects were observed for all compounds. Because of strong cytotoxic effects, 6 was not included in these assays.

In the mouse ear assay however, two compounds, mevinic acid and phomol, showed signifi-

\begin{tabular}{lcc}
\hline Substance & $\begin{array}{c}\text { Edema [mg] } \\
(\text { mean } \pm \text { SEM) }\end{array}$ & Edema inhibition (\%) \\
\hline Control & $17.82 \pm 0.71$ & \\
Phomol (15) (1 mg/ear)* & $8.34 \pm 1.11$ & 53.20 \\
Mevinic acid (13) (1 mg/ear) & $8.64 \pm 0.98$ & 51.51 \\
Mellein (11) (1 mg/ear) & $13.85 \pm 0.79$ & 22.28 \\
Nectriapyrone (14) (1 mg/ear) & $14.3 \pm 0.78$ & 19.75 \\
Indomethacin (0.5 mg/ear) & $6.01 \pm 0.69$ & 66.00 \\
\hline
\end{tabular}

Table VI. Topical anti-inflammatory activities in TPA-induced mouse ear edema.

* Weber et al., 2004. 
cant activities (Table VI). The anti-inflammatory effect of mevinic acids (statins) are clinically proven. Ongoing experiments will show if both compounds are present in the plant and contribute to its anti-inflammatory activities.

\section{Acknowledgements}

We thank Dr. Roland Weber for support in phylogenetic analysis, Dr. Bärbel Köpcke for help with the test for nematicidal activity, and Meike Saul for expert technical assistance with TNF- $\alpha$ and STAT1/STAT2 reporter gene asssays.

The project "New pharmacologically active metabolites of Argentinean medicinal plants and their endophytic fungi" is supported by the VWStiftung, the Fonds der Chemischen Industrie, BMBF, and the Secretaría para la Tecnología, la Ciencia y la Innovación Productiva (SETCIP).
Anke H., Bergendorff O., and Sterner O. (1989), Assay of the biological activities of guaiane sesquiterpenoids isolated from the fruit bodies of edible Lactarius species. Food. Chem. Toxicol. 27, 393-398.

Bell A. A. and Wheeler M. H. (1986), Biosynthesis and function of fungal melanins. Annu. Rev. Phytopathol. 24, 411-451.

Carmarda L., Merlini L., and Nasini G. (1976), Metabolites of Cercospora. Taiwapyrone, an $\alpha$-pyrone of unusual structure from Cercospora taiwanensis. Phytochemistry 15, 537-539.

Carlson R., O'Neill-Davis L., and Lewis A. (1985), Modulation of mouse ear oedema by cyclooxyganase and lipoxyganase inhibitors and other pharmacologic agents. Agents Actions 17, 198-204.

Chu M., Mierzwa R., Xu L., He L., Terracciano J., Patel M., Gullo V., Black T., Zhao W., Chan T.-M., and McPhail A. T. (2003), Isolation and structure elucidation of Sch 642305, a novel bacterial DNA primase inhibitor produced by Penicillium verrucosum. J. Nat. Prod. 66, 1527-1530.

Claydon N., Grove J. F., and Pople M. (1985), Elm bark beetle boring and feeding deterrents from Phomopsis oblonga. Phytochemistry 24, 937-943.

Cross B. E., Galt R., Hanson H. B., J. R., Curtis P. J., Grove J. F., and Morrison A. (1963), New metabolites of Gibberella fujikuroi. Part II. The isolation of fourteen new metabolites. J. Chem. Soc., 2937-2943.

Devys M., Bousquet J. F., and Barbier M. (1976), Le tyrosol ( $p$-hydroxyphenylethanol) inhibiteur de la germination isolé du milieu de culture de Pyricularia oryzae. Phytopath. Z. 85, 176-178.

De Young L., Kheifts J., Ballaron S., and Young J. (1989), Edema and cell infiltration in the phorboltreated mouse ear are temporally separate and can be differentially modulated by pharmacological agents. Agents Actions 26, 335-341.

Endo A. and Hasumi K. (1997), Mevinic acids. In: Fungal Biotechnology (Anke T., ed.). Champman \& Hall, London. pp. 162-172.

Erkel G., Anke T., and Sterner O. (1996), Inhibition of $\mathrm{NF}-x \mathrm{~B}$ activation by panepoxydone. Biochim. Biophys. Res. Commun. 226, 214-221.
Grove J. F. and Pople M. (1979), Metabolic products of Fusarium larvarum Fuckel. The fusarentins and the absolute configuration of moncerin. J. Chem. Soc. Perkin Trans. 1, 2048-2051.

Hassal C. H. and Todd A. R. (1947), The structure of clavatol, a metabolic product of Aspergillus clavatus. J. Chem. Soc., 611-613.

Hawksworth D. L. (1991), The fungal dimension of biodiversity: magnitude, significance, and conversation. Mycol. Res. 95, 641-655.

Köpcke B., Weber R. W. S., and Anke H. (2002), Galliellalactone and its biogenetic precursors as chemotaxonomic markers of the Sarcosomataceae (Ascomycota). Phytochemistry 60, 709-714.

Miño J., Gorzalczany S., Moscatelli V., Ferraro G., Acevedo C., and Hnatyszyn O. (2002), Actividad antinociceptiva y antinflamatoria de Erythrina crista-galli (Ceibo). Acta . Farm. Bonaerense 21, 93-98.

Mitscher L. A., Gollapudi R. S. R., Gerlach D. C., Drake S. D., Veliz E. A., and Ward J. A. (1988), Erycristin, a new antimicrobial petrocarpan from Erythrina cristagalli. Phytochemistry 27, 381-385.

Nair M. S. R. and Carey S. T. (1975), Metabolites of Pyrenomycetes II: Nectriapyrone, an antibiotic monoterpenoid. Tetrahedron Lett. 19, 1655-1658.

Nishikawa W. (1933), A metabolic product of Aspergillus melleus Yukawa. J. Agric. Chem. Soc. Jpn. Chem. 9, 772; Chem. Abstr. 28, 2751 (1934).

Pedras M. S. C., Morales V. M., and Taylor J. L. (1994), Phomapyrones: Three metabolites from the blackleg fungus. Phytochemistry 36, 1315-1318.

Pfunder M., Schürch S., and Roy B. A. (2001), Sequence variation and geographic distribution of pseudoflower-forming rust fungi (Uromyces pisi s. lat.) on Euphorbia cyparissias. Mycol. Res. 105, 57-66.

Rizzo I., Varsavky E., Haidukowski M., and Frade H. (1997), Macrocyclic trichothecenes in Baccharis coridifolia plants and endophytes and Baccharis artemisioides plants. Toxicon 35, 753-757.

Stadler M., Mayer A., Anke H., and Sterner O. (1994), Fatty acids and other compounds with nematicidal activity from cultures of Basidiomycetes. Planta Med. 60, 128-132. 
Stierle A., Strobel G., and Stierle D. (1995), The search for a taxol-producing micoorganism among the endophytic fungi of the pacific yew, Taxus brevifolia. J. Nat. Prod. 58, 1315-1324.

Stone J. K., Bacon C. W., and White J. F. (2000), An overview of endophytic microbes: Endophytism defined. In: Microbial Endophytes (Bacon C. W. and White J. F., eds.). Marcel Dekker, New York, pp. 389-420.

Strobel G. A. (2002), Rainforest endophytes and bioactive compounds. Critical Rev. Biotechnol. 22, 315333.

Takeuchi N., Goto K., Sasaki Y., Fujeta T., Okazaki K., Kamata K., and Tobinaga S. (1992), Synthesis of (+)and (-)-mellein utilizing an annelation reaction of isoxazoles with dimethyl-3-oxoglutarate. Heterocycles 33, 357-374.

Toursarkissian M. (1980), Plantas Medicinales de la Argentina. Hemisferio Sur Editorial, Buenos Aires, p. 70.

Uecker F. A. (1988), A world list of Phomopsis names with notes on nomenclature, morphology and biology. J. Cramer Verlag, Berlin, Stuttgart.

Wani M. V., Taylor H. L., Wall M. E., Coggon P., and McPhail A. T. (1971), Plant antitumor agents VI. The isolation and structure of taxol, a novel antileukemic and antitumor agent from Taxus brevifolia. J. Am. Chem. Soc. 93, 2325-2327.
Webber J. (1981), A natural biological control of Dutch elm disease. Nature 292, 449-451.

Weber D., Sterner O., Anke T., Gorzalczancy S., Martino V., and Acevedo C. (2004), Phomol, a new antiinflammatory metabolite from an endophyte of the medicinal plant Erythrina crista-galli. J. Antibiot. 57, 559563.

Weidler M., Rether J., Anke T., and Erkel G. (2000), Inhibiton of interleukin-6 signaling by galiellalactone. FEBS Lett. 484, 1-6.

Wenke J. (1993), Isolierung und Charakterisierung neuer Inhibitoren der Chitinsynthase aus höheren Pilzen. $\mathrm{PhD}$ Thesis. Universität Kaiserslautern.

White T. J., Bruns T., Lee S., and Taylor J. (1990), Amplification and direct sequencing of fungal ribosomal RNA genes for phylogenetics. In: PCR Protocols: A Guide to Methods and Applications (Innis M. A., Gelfand D. H., Sninsky J. J., and White T. J., eds.). Academic Press, San Diego, pp. 315-322.

Wilson D. (2000), Ecology of woody plant endophytes. In: Mycrobial Endophytes (Bacon C. W. and White J. F., eds.). Marcel Dekker, New York, pp. 389420.

Zapf S., Hoßfeld M., Anke H., Velten R., and Steglich W. (1995), Darlucins A and B, new isocyanide antibiotics from Sphaerellopsis filum (Darluca filum). J Antibiot. 48, 36-41. 